\title{
A promoção turística de Cabo Verde no mercado português
}

\section{Filipa Fernandes* Raquel Barbosa Ribeiro** Louisiene Lima*** \\ Universidade de Lisboa (Portugal)}

\begin{abstract}
Resumo: Cabo Verde é um destino turístico com aumento regular da procura, ao qual se aponta grande potencial futuro. A comunicação de um destino é imprescindível para divulgá-lo e torná-lo conhecido. Neste artigo, descreve-se como se processa a promoção turística do destino Cabo Verde para o mercado exterior, com enfoque no mercado português. Identifica-se o papel de cada interveniente turístico público e privado, cabo-verdiano e português, neste processo. Visa-se, adicionalmente, avaliar o conhecimento e a atitude dos turistas portugueses relativamente a tal promoção. Para responder a estes objetivos recorreu-se a entrevistas realizadas a entidades envolvidas na promoção do destino e aplicou-se inquéritos a 291 turistas portugueses. Verificou-se que a comunicação turística do destino depende muito de operadores turísticos ou intervenientes privados, tendo sido, por isso, recomendadas melhorias à estratégia de comunicação turística de Cabo Verde.

Palavras-chave: Cabo Verde; Turismo; Marketing turístico; Comunicação; Promoção turística.
\end{abstract}

\section{Capeverdian tourism promotion in the portuguese market}

Abstract: Cape Verde is a growingly sought-after tourist destination with great future potential. The communication of a destination is paramount to make it known. In this article, we describe how Cape Verde has been promoted in external markets, namely in the Portuguese. The intention is to identify the role played by both Cape-Verdean and Portuguese public and private stakeholders. Additionally, the objetive is to assess the knowledge and attitude of Portuguese tourists as regards the communication and promotion of Cape Verde. To answer these questions, interviews were carried out to organizations involved in the promotion of the destination and 291 Portuguese tourists were surveyed. Results show that tourist communication of a destination is much dependent of tour operators and private actors. In face of these conclusions, it is recommended that the communication strategy of Cape Verde should be improved.

Keywords: Cape Verde; Tourism; Tourism marketing; Communication; Tourism promotion.

\section{Introdução}

O turismo é considerado um dos fatores para o desenvolvimento económico dos países em vias de desenvolvimento. Neste âmbito, Cabo Verde tem sido apontado como um destino turístico por excelência, com um aumento regular da procura e com grande potencial de desenvolvimento turístico futuro (Ribeiro, 2016). Este artigo pretende contribuir cientificamente para o conhecimento e desenvolvimento de um destino ainda pouco estudado, que pode beneficiar de recomendações para tornar a sua comunicação turística mais eficaz (Fernandes, 2016a).

O setor do turismo constitui um dos setores-chaves no fomento do desenvolvimento sustentável de ilhas (UNWTO, 2013) e a razão de ser do turismo em qualquer área ou região nos países em desenvolvimento é o seu possível contributo para o desenvolvimento (Fernandes, 2016b). O turismo é considerado um dos principais vetores de crescimento económico e um instrumento muito válido na redução e combate

Centro de Estudos Africanos e Centro de Administração e Políticas Públicas, Instituto Superior de Ciências Sociais e Políticas, Universidade de Lisboa; E-mail: ffernandes@iscsp.ulisboa.pt

* Centro de Administração e Políticas Públicas, Instituto Superior de Ciências Sociais e Políticas, Universidade de Lisboa; E-mail: rribeiro@iscsp.ulisboa.pt

*** ISCSP-Universidade de Lisboa; E-mail: low.sl@hotmail.com 
à pobreza nos países em desenvolvimento, pelo que está cada vez mais presente na arena política mundial (Canalejo et al., 2014, p. 367).

Num cenário de desenvolvimento, a comunicação do destino, com o intuito primário de divulgá-lo e granjear-lhe notoriedade, assume um papel de relevo. A comunicação realizada pelas organizações responsáveis pela promoção de um destino turístico é uma das melhores formas de torná-lo conhecido e desempenha um papel fulcral na procura de destinos, já que influencia comportamentos ao seduzir o turista (Fernandes et al., 2018). Quando bem utilizada, esta comunicação contribui diretamente para o aumento da procura. Mas, além da notoriedade, também o renome, a imagem e o posicionamento do destino podem determinar a preferência dos turistas no momento da escolha. Assim, tem sido defendido que é crucial adequar a comunicação estratégica de um destino às necessidades e motivações de cada segmento dos seus consumidores (Ruschmann, 2001, p. 43). É também importante avaliar o resultado da utilização das ferramentas de comunicação, através do feedback do seu público-alvo. Quaresma et al. (2018) acrescentam, a propósito, que a utilização das novas tecnologias de informação e comunicação revolucionaram o setor do turismo e a sua utilização permite que os destinos turísticos retirem vantagens para a gestão, planeamento e marketing.

Neste artigo, descreve-se como se processa a promoção turística de Cabo Verde para o mercado exterior, mais concretamente para o mercado português. Identifica-se o papel de cada interveniente turístico público e privado, cabo-verdiano e português, neste processo. Visa-se, adicionalmente, avaliar o conhecimento e a atitude dos turistas portugueses relativamente a tal promoção.

\section{Enquadramento teórico}

O turismo representa um modo de vida das sociedades modernas, constituindo uma consequência de necessidades nos domínios do lazer, da cultura, da religião, da atividade profissional e do conhecimento de outras terras e outros povos (Costa et al., 2001, p. 2). A Organização Mundial do Turismo (OMT, 1998) carateriza-o como um fenómeno social, cultural e económico que implica a deslocação de pessoas para países ou lugares fora do seu ambiente habitual para fins pessoais ou de negócios/profissionais.

O marketing e a promoção turística integram o planeamento do turismo e fazem parte das políticas nacionais para o desenvolvimento turístico, sendo essenciais para a afirmação da imagem turística dos destinos nos mercados internos e externos (Fernandes, 2016a, p. 321). O marketing é o conjunto de conhecimentos e procedimentos que as organizações podem usar para atingir os seus objetivos, através da satisfação de necessidades e desejos de consumidores (ou clientes), num processo relacional de benefício recíproco que se traduz numa troca (Ribeiro \& Soares, 2015).

O marketing turístico visa "equilíbrio entre a satisfação das necessidades dos turistas e os interesses dos destinos ou das organizações" (Baptista, 2003, p. 53) e tem vindo a ser cada vez mais utilizado pelos operadores de mercado de diferentes destinos turísticos, de modo a captar mais e melhores turistas e assim aumentar a sua quota de mercado. Para Madeira (2010, p.23), o marketing de turismo abrange a pesquisa e análise das necessidades e expetativas dos turistas, cooperando com organismos locais, regionais, nacionais e internacionais com vista à sua satisfação. $\mathrm{O}$ marketing pode ser determinante na comunicação das potencialidades dos destinos turísticos e na promoção das caraterísticas endógenas que os diferenciam de outros destinos, quer ao nível dos residentes, quer dos visitantes e dos potenciais investidores que pretendem localizar empresas num determinado destino (Rita, 2014, p. 187). Embora o marketing tenha sido acusado de promover a exploração, o esgotamento dos recursos e o consumo hedonista, pode ser também um instrumento de promoção da sustentabilidade e da mudança de comportamentos, com aplicação ao turismo (Font \& McCabe, 2017; veja-se também a proposta de Marketing 3.0 de Kotler, Kartajaya e Setiawan, 2010).

A comunicação integrada de marketing define-se pela combinação de meios que possibilitam o diálogo com o mercado com técnicas de comunicação que contribuem para a divulgação da mensagem do emissor, maximizando a informação do produto ou serviço disponibilizada ao mercado (Sebastião, 2016, p. 202). Esta comunicação visa informar, divulgar, dar a conhecer, dar notoriedade, promover a experimentação, estimular a compra, preparar a venda, promover a fidelização, combater a sazonalidade, credibilizar e promover a imagem, vender e escoar produtos, transmitir confiança e envolver.

A comunicação turística inclui a comunicação gerada pelas relações de turismo, formais ou informais, com a finalidade de dar a conhecer o destino ao público, persuadir o turista a sentir-se seduzido pelo destino, e manter a divulgação para relembrar o visitante dos atrativos do destino (Fernandes et al., 2018). A comunicação das organizações turísticas implica um número significativo de segmentos de 
mercado, disseminados por diversas regiões e países, bem como o recurso a diferentes técnicas e canais de comunicação (Cosma et al., 2012, p. 112). Este é o trabalho da comunicação integrada de marketing (Sebastião, 2016, pp. 203-204), que inclui técnicas consideradas "tradicionais" como a publicidade, as relações públicas de marketing, a promoção de vendas, a força de vendas e o marketing directo; e outras mais inovadoras, que tiram partido do online e visam minorar o efeito de saturação dos consumidores e envolvê-los na promoção dos produtos, serviços e marcas, como social media, mobile marketing, soft sponsoring ou branded content. No setor do turismo, os destinos turísticos são os que mais beneficiam do desenvolvimento das tecnologias de informação, uma vez que retiram vantagem destas novas ferramentas estratégicas para a gestão, planeamento e marketing (Buhalis, 2000, p. 55).

A promoção turística refere-se à atividade comunicativa de marketing que preenche as lacunas de perceção e informação que existem entre os fornecedores de turismo e os turistas (Esu, 2010, p. 3). É concebida com o intuito de divulgar e criar uma imagem positiva e atrativa aos olhos de quem não conhece o destino. Pode ser projetada tanto para persuadir racionalmente, fornecendo informações fatuais de que os potenciais visitantes necessitam para a tomada de decisão, como para persuadir emocionalmente. Uma das tarefas primordiais a ter em conta antes da criação de mensagens promocionais é entender e conhecer o consumidor e qual o público-alvo que se pretende atingir, porque disso depende a eficácia da comunicação (Ramos \& Ribeiro, 2014).

O processo de promoção de um destino turístico envolve vários intervenientes que, em conjunto, atuam de forma a possibilitar o processo de deslocação turística. As atividades de promoção dos países enquanto destino turístico vêm sendo asseguradas por organismos estatais e privados. Dentro dos organismos privados, podemos destacar os operadores turísticos e as agências de viagens, entre outros. Dos organismos estatais, destacam-se os Organismos Nacionais de Turismo (ONT), oficialmente reconhecidos como organizações especialistas em turismo num determinado país. Através desta sua organização não lucrativa, o Estado desempenha um papel crucial no marketing do país enquanto destino turístico internacional (Costa et al., 2001, p. 89), não se envolvendo diretamente nas vendas ou distribuição (Cunha, 2013). O seu campo de atuação situa-se, na maior parte das vezes, nas operações de publicidade, de marketing, de relações públicas ou de participação em eventos especiais, nos estudos de mercado, nas pesquisas, na prestação de informações, nas promoções, no relacionamento com outros órgãos públicos ou privados, na ordenação turística, no planeamento turístico, na fiscalização e controle da qualidade, nas campanhas de consciencialização e na preparação de recursos humanos. A sua ação pode realizar-se no próprio país pelo apoio, ou pela organização direta de acontecimento especiais que promovam a imagem do país externa ou internamente (Cunha, 2013, p. 423).

Como referem Ramos e Ribeiro (2014), o marketing territorial (ou dos destinos) implica a análise das necessidades dos stakeholders e consumidores no sentido de criar, manter e reforçar com eles relações de troca, com o objetivo final de aumentar o valor e a atractividade de um local. Os autores acrescentam que "o marketing territorial não deve ser fortuito ou meramente promocional, antes requer cooperação entre as autoridades locais e o setor público, a contribuição directa dos cidadãos e um planeamento estratégico eficaz" (Ramos \& Ribeiro, 2014, pp. 16-17).

A comunicação no turismo compreende três fases: antes, durante e depois da prestação dos serviços (DiPietro, 2007; Marujo, 2008). A primeira fase consiste na recolha de informações sobre o destino. Existem várias fontes de informação que os turistas podem consultar antes de viajar para um destino: meios de comunicação social (televisão, imprensa, rádio, cinema, outdoor, internet), feiras de turismo e "passa-a-palavra" ou word-of-mouth, entre outras. A segunda fase, que ocorre durante a viagem, estabelece-se com o turista já no destino, e consiste nas relações culturais e de lazer entre os turistas e residentes e dos turistas entre si. Por fim, a terceira fase que acontece após a viagem, consiste na descrição das experiências vivenciadas pelos turistas no destino, tendencialmente a amigos, familiares e colegas. Essas experiências tanto podem ser descritas de forma positiva ou negativa, dependendo do grau de satisfação dos turistas relativamente ao destino. Esta última fase (depois da viagem) é de extrema importância para avaliação da eficácia da promoção de um destino, uma vez que é nesta fase que os turistas dão o seu feedback relativamente ao destino no geral. O feedback no turismo atua como instrumento de avaliação, ganhando assim uma especial relevância já que, a partir da avaliação da reação do recetor, o emissor consegue saber se o seu objetivo foi ou não alcançado. Desta forma, é possível controlar os efeitos do processo comunicacional e adaptar melhor o produto aos desejos dos turistas. A conjugação destas três fases contribui para a formação da imagem do produto/destino e das empresas turísticas que participam na promoção do destino.

Bolaños e outros (2014) destacam as preferências dos turistas portugueses pelas informações de outros viajantes ou de conhecidos (word-of-mouth e conteúdos gerados por utilizadores), seguindo-se o 
contributo de organismos oficiais, publicações turísticas, hotéis e agências de viagens. Os autores frisam a importância do word-of mouth ou WOM (comunicação de marketing centrada no consumidor, sendo o emissor independente do vendedor) e do conteúdo gerado por utilizadores (produzido por pessoas comuns que contribuem de forma voluntária com dados ou informações, tais como textos, fotografias, marcadores, áudio ou vídeo, que estão disponíveis online e acessíveis a qualquer pessoa) no desenvolvimento da comunicação turística contemporânea.

\section{O destino turístico Cabo Verde: caraterização, procura e oferta}

Cabo Verde é um território de origem vulcânica, situado no Oceano Atlântico, a cerca de $455 \mathrm{Km}$ do cabo homónimo, no extremo ocidental africano. Está localizado na zona sub-saheliana e possui um clima subtropical seco moderado pelos ventos alísios. É constituído por 10 ilhas, 9 delas habitadas, divididas em dois grupos: ao norte, as ilhas de Barlavento. De oeste para leste: Santo Antão, São Vicente, Santa Luzia (desabitada e reserva natural), São Nicolau, Sal e Boa Vista. Ao Sul, as ilhas de Sotavento. Enumerando de leste para oeste: Maio, Santiago, Fogo e Brava (Guia turístico de Cabo Verde, 2014, p. 14).

Com uma superfície de $4.033 \mathrm{~km}$, o país teria cerca de 561.000 habitantes em Julho de 2017, estimando-se que quase 50\% da população tenha até 24 anos de idade (CIA, 2018). Cabo Verde tem das taxas de alfabetização mais altas da CPLP, enquanto as suas taxas de inflação e de pobreza são das mais reduzidas (Ribeiro, 2016, p. 100). O país apresenta desde 1975 índices de crescimento económico muito elevados, estimando-se atualmente que o rendimento médio/anual per capita se situa nos US\$ 2.000. O seu desenvolvimento económico ficou patente a 1 de Janeiro de 2008, quando deixou de constar da lista dos Países Menos Avançados (PMA), adquirindo o status de Países de Rendimento Médio (PRM) (Canalejo et al., 2014, p. 370). A estrutura económica está condicionada pela insularidade e pela vulnerabilidade face ao exterior, o que tem vindo a provocar alguns problemas financeiros e técnicos para o desenvolvimento da energia, da água, da saúde e dos transportes, assim como o crescimento dos custos de produção.

A economia cabo-verdiana baseia-se no setor dos serviços, que pesa mais de $75 \%$ do PIB (Ribeiro, 2016), sendo o comércio, o transporte, o turismo e os serviços públicos os mais expressivos (Fernandes, 2016b). A estabilidade política, o investimento na educação e as receitas dos emigrantes são as principais razões do seu relativo êxito (Canalejo et al., 2014, p. 371).

Segundo o Plano de Marketing do Turismo de Cabo Verde 2015/2016 (Ministério de Turismo, Investimentos e Desenvolvimento Empresarial, 2015), o turismo é o sétimo setor da economia que mais contribui para o PIB (7,2\% em 2014) e tem vindo a ser considerado um dos principais motores da economia cabo-verdiana (Fernandes, 2016b). Cabo Verde deu um salto qualitativo e quantitativo na última década, impulsionado, sobretudo, pelo grande desempenho do setor turístico, em associação estreita com o setor da construção (Canalejo et al., 2014, p. 371).

Cabo Verde possui um elevado potencial turístico, "tanto por ser um lugar seguro como por ter um clima agradável durante todo o ano e atrativos turísticos diferentes em cada uma das suas dez ilhas. Para além de uma boa relação com a sua diáspora, e das importantes conquistas democráticas, beneficia também da sua localização geoestratégica para o transporte internacional" (Canalejo et al., 2014, p. 367). Conta com temperaturas amenas durante todo o ano oferecendo condições ideais para a prática de desportos náuticos, desde o surf, windsurf e kitesurf, ao mergulho, pesca e natação. As praias de Cabo Verde adequam-se bem à procura dos amantes de sol e mar, sendo estes os principais produtos turísticos do país. Porém, existem alguns constrangimentos relativos à dimensão dos acessos, à dimensão da infraestrutura geral, e à dimensão da infraestrutura turística, que limitam a potencialização da atividade turística no país.

O mercado turístico cabo-verdiano carateriza-se por uma procura externa por parte dos mercados emissores de turistas, com uma tendência de grande crescimento. Apesar de uma ligeira retração da procura entre 2008 e 2010 (mais visível nas receitas turísticas), anos que coincidem com os impactos severos da crise financeira global, a indústria demonstrou uma forte resiliência, tendo recuperado e ultrapassado os valores pré-crise (Ministério de Turismo, Investimentos e Desenvolvimento Empresarial, 2015). Os principais mercados emissores de turistas para o destino são Reino Unido, Alemanha, França e Portugal (INE CV, 2014).

Os dados constantes dos Gráficos 1 e 2 revelam uma tendência positiva de crescimento até 2013 no que concerne ao número de hóspedes, ao número de dormidas, e da estada média em Cabo Verde. Estes indicadores sofreram algumas quebras nos anos seguintes. 
Gráfico 1: Evolução de hóspedes e dormidas em Cabo Verde (2002-2014)

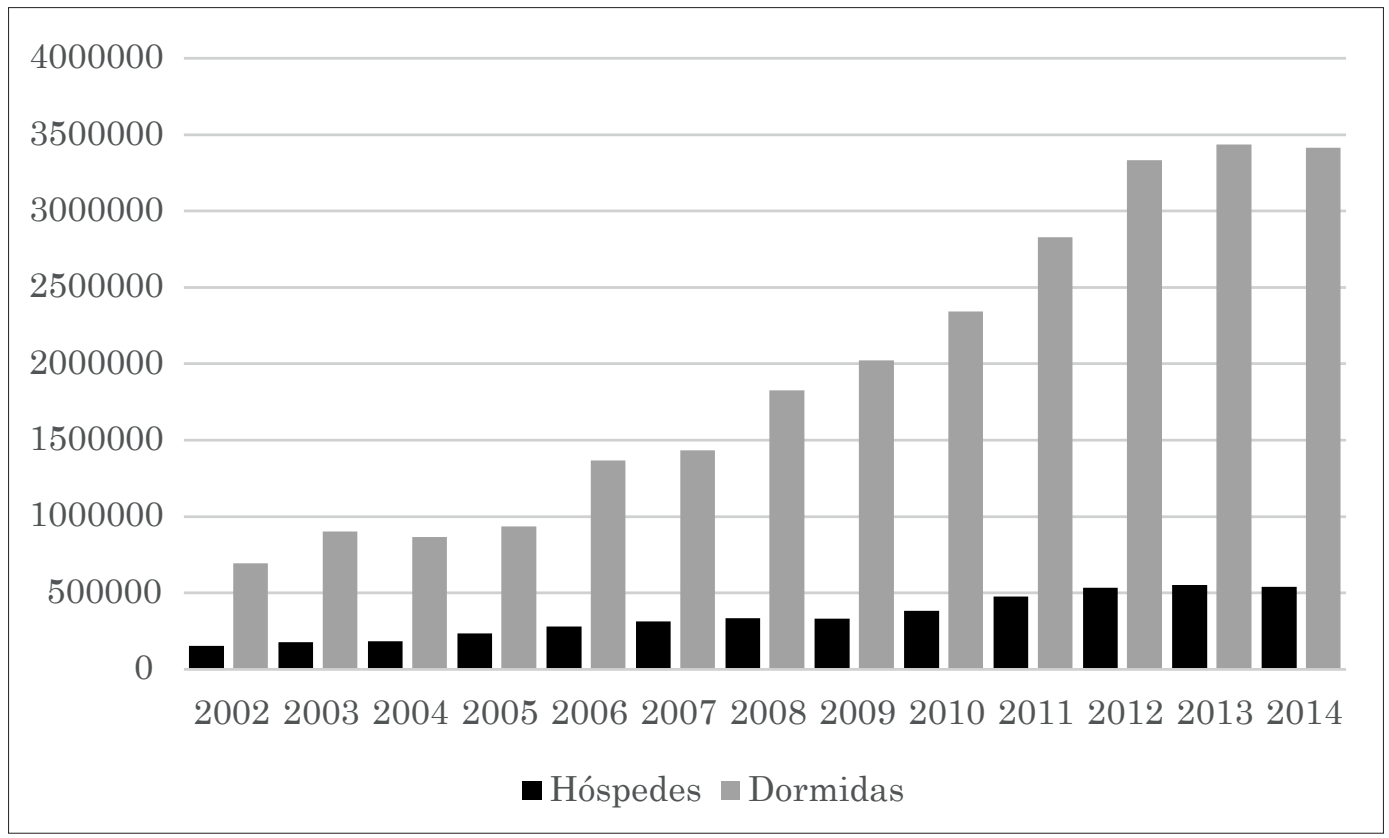

Fonte: Elaboração própria com base em dados do INE CV (2002-2014).

\section{Gráfico 2: Evolução da duração da taxa de ocupação/cama e da estada média em Cabo Verde (2002-2014)}

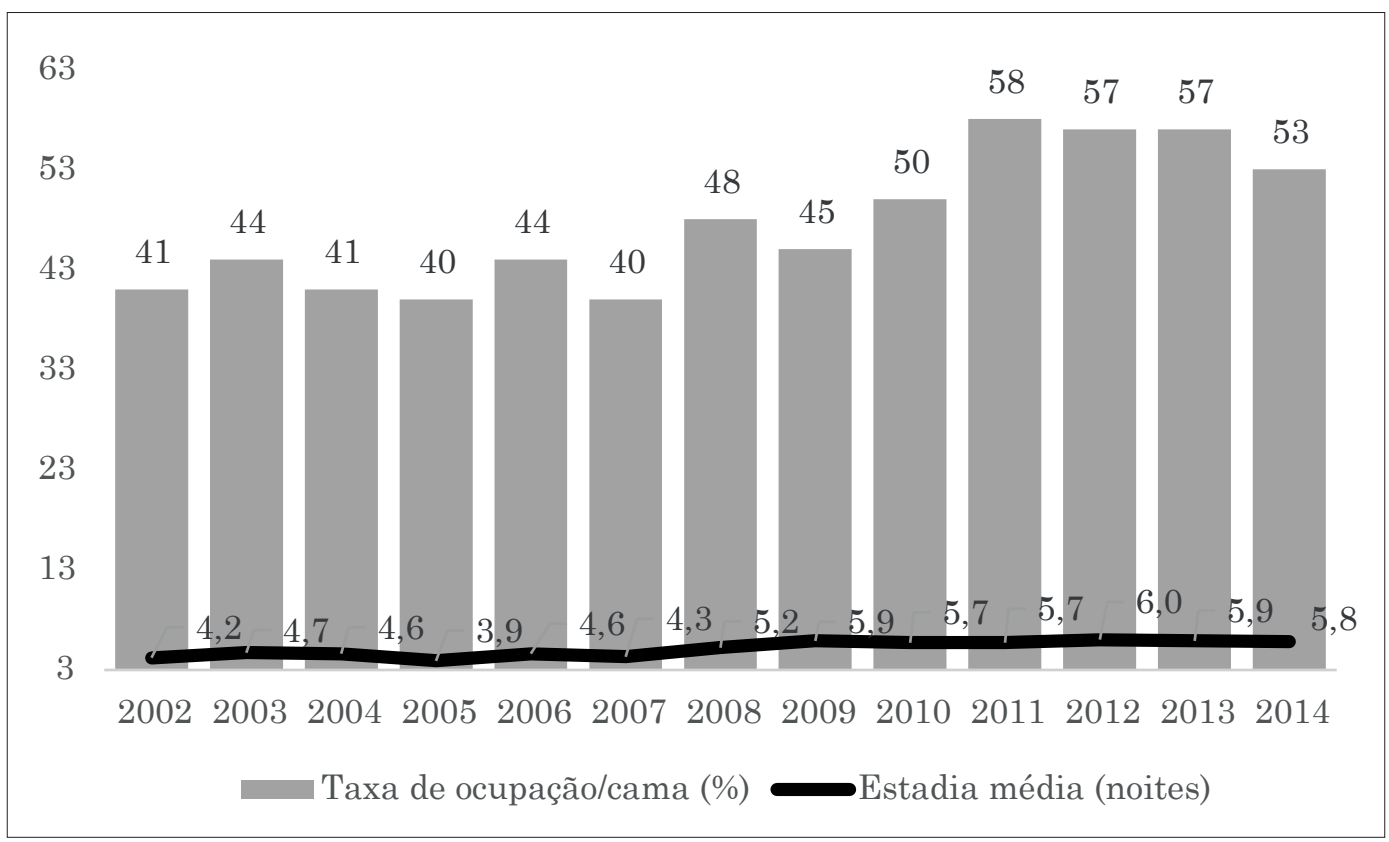

Fonte: Elaboração própria com base em dados do INE CV (2002-2014). 
No que toca à evolução dos turistas portugueses em Cabo Verde, os dados acerca do número de entradas e do número de dormidas apresentados no Gráfico 3 revelam alguma oscilação de valores.

\section{Gráfico 3: Entradas e dormidas de portugueses em Cabo Verde (2000-2014)}

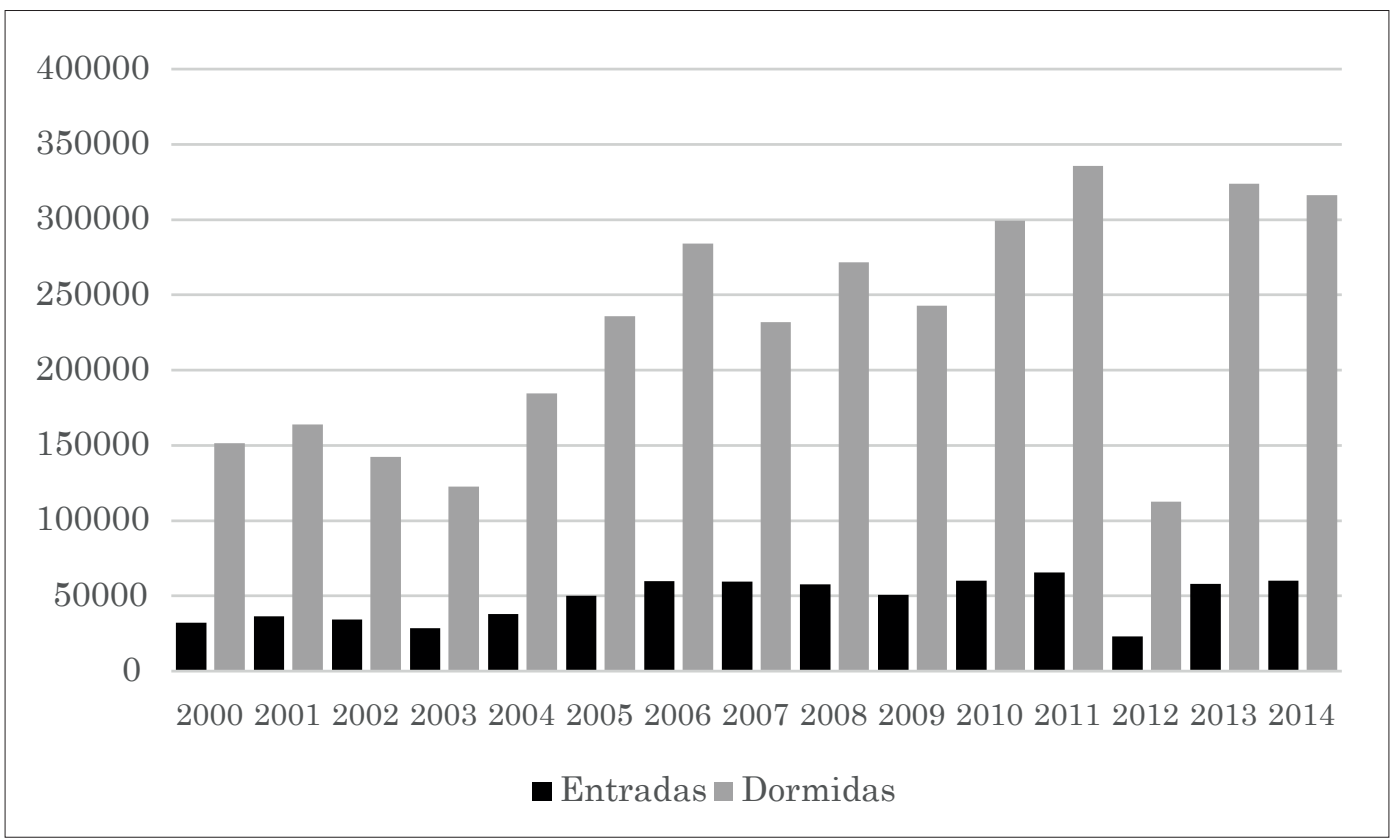

Fonte: Elaboração própria com base em dados do INE CV (2002-2014).

Podemos constatar que tanto as entradas como as dormidas dos turistas portugueses no destino Cabo Verde têm vindo a aumentar de forma praticamente ininterrupta, com excepção para 2012 (ano de crise económica com forte retração do consumo). Saliente-se, porém, que os portugueses pesavam cerca de $21 \%$ nas entradas e dormidas em 2000, mas apenas $10 \%$ em 2014, sinal da diversificação da origem dos turistas que visitam Cabo Verde ao longo deste intervalo de tempo.

Como ilustra o Gráfico 4, o número de estabelecimentos hoteleiros tem vindo a aumentar desde 2008. O número de quartos, bem como o número de camas, aumentaram $20 \%$ e $14 \%$, respetivamente, entre 2013 e 2014. 
Gráfico 4: Evolução das infraestruturas turísticas de Cabo Verde (2008-2014)

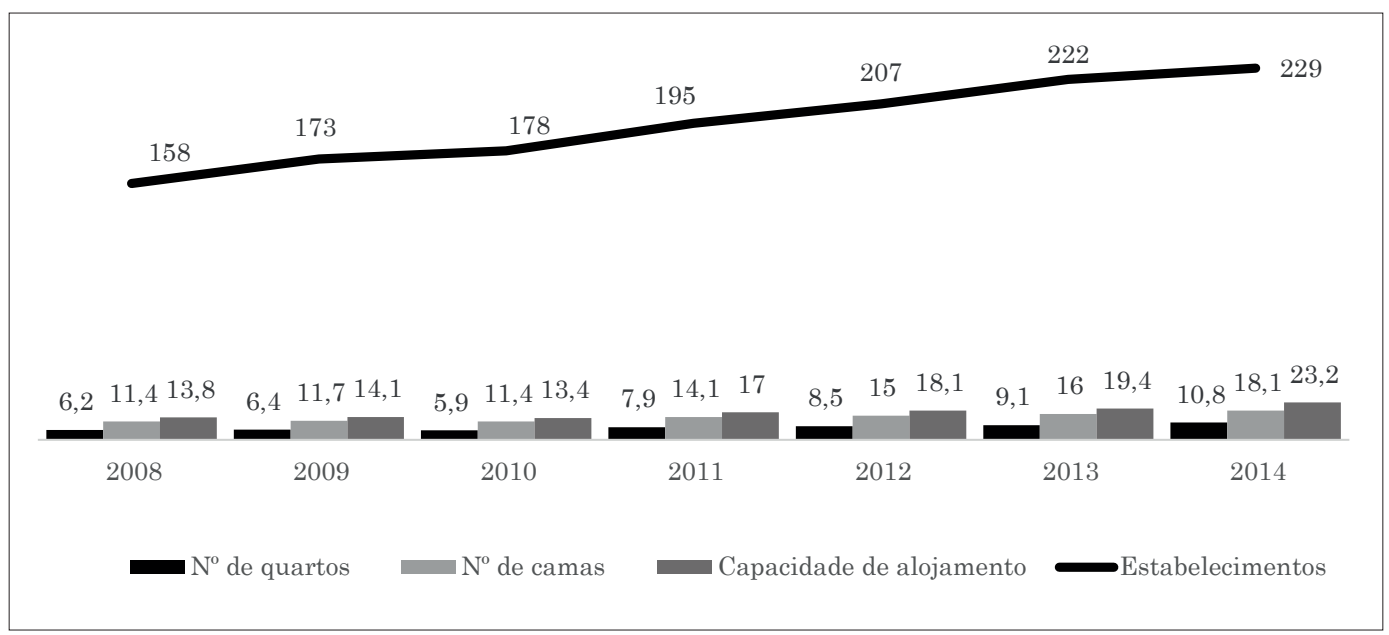

Fonte: INE CV, 2015.

Relativamente aos estabelecimentos de alojamento disponíveis por ilha, estes encontram-se distribuídos de forma irregular, concentrando-se mais nas ilhas de Santiago (22\%), Santo Antão (18\%) e São Vicente (16\%). No entanto, as ilhas com maior procura turística são a ilha do Sal com 41,5\% do total de entradas, seguida da ilha de Boavista com 43,1\% (INE CV, 2014).

\section{Metodologia}

Este artigo deriva de um estudo exploratório, assente num método quanti-qualitativo e que recorre ao estudo do caso de Cabo Verde, em que "os resultados obviamente não podem ser generalizados à população à qual pertence o grupo de conveniência, mas do qual se poderão obter informações preciosas, embora não as utilizando sem as devidas cautelas e reservas" (Carmo \& Ferreira, 2008, p. 215).

Estabeleceu-se como pergunta de partida: como se processa a comunicação e a promoção turística de Cabo Verde? O objetivo geral é averiguar como se concretiza a promoção turística deste destino para o mercado exterior. Pretende-se, adicionalmente, descobrir como esta promoção são avaliadas pelos turistas a que se destinam. De acordo com Marujo (2008), a noção de feedback na comunicação em turismo ganha uma especial relevância uma vez que, a partir de uma avaliação do recetor, o emissor recebe informações sobre o cumprimento do seu objetivo e pode adaptar os seus esforços aos desejos da audiência. Para uma operacionalização objetiva, o estudo centrou-se na emissão e na receção de tais esforços de comunicação e a promoção turística para o mercado português, que é o mais relevante para Cabo Verde.

Considerando que a comunicação no turismo abarca três tempos, antes da viagem, durante a viagem e depois da viagem (Marujo, 2008), definiu-se como objetivos específicos:

1) Compreender o papel das instituições oficiais cabo-verdianas e dos intervenientes privados cabo-verdianos e portugueses na promoção de Cabo Verde enquanto destino turístico;

2) Identificar os instrumentos e ferramentas de comunicação utilizados na promoção do destino, por essas mesmas instituições;

3) Apurar que fontes de informação os turistas portugueses que viajaram para Cabo Verde consultaram antes de viajarem;

4) Aferir como os turistas portuguesas que viajaram para Cabo Verde avaliam a promoção turística desse destino;

5) Apurar que fontes de informação os inquiridos portugueses que nunca visitaram o destino consultariam antes de viajarem para Cabo Verde

6) Aferir como os turistas portuguesas que nunca viajaram para Cabo Verde avaliam a promoção turística desse destino. 


\subsection{Recolha qualitativa}

Recorreu-se a entrevistas semiestruturadas para avaliar o papel das instituições oficiais cabo-verdianas e dos intervenientes privados cabo-verdianos e portugueses na promoção de Cabo Verde enquanto destino turístico, assim como para identificar que instrumentos de comunicação são utilizados na promoção do destino por essas instituições oficiais e intervenientes privados. Apresenta-se seguidamente uma listagem das instituições contactadas:

1) Direção Geral de Turismo de Cabo Verde (instituição oficial)

A entrevista foi respondida pela assessora da Ministra do Turismo, Investimentos e Desenvolvimento Empresarial de Cabo Verde, Dália Gomes, em Novembro de 2015.

2) Agências de viagens cabo-verdianas (intervenientes privados)

Entrevistou-se representantes das agências de viagens Atlantur (com respostas de Nilton Soares) e Tropictour (com o contributo de Helda Andrade), ambas situadas na cidade de Mindelo (ilha de São Vicente), em Setembro de 2014

3) Agências de viagens portuguesas (intervenientes privados)

Pelo seu pioneirismo e liderança no mercado turístico português, recorreu-se à agência de viagens Abreu. Entrevistou-se a assistente Vânia da agência situada no Centro Comercial Colombo, em Lisboa, Portugal, em Outubro de 2014.

4) Operadores turísticos portugueses (intervenientes privados)

Entrevistou-se os operadores turísticos Solférias (representada pela diretora comercial Sónia Regateiro) e Soltrópico (através do diretor comercial Nuno Anjos), em Lisboa, Portugal, em Maio de 2015.

5) Hotéis cabo-verdianos (intervenientes privados)

Consultou-se a diretora comercial, Lenilda Maocha, do Hotel Dom Paco e do Hotel Oásis Atlântico (ambos na ilha de São Vicente), em Setembro de 2014.

Refira-se ainda que tentou entrevistar-se o operador turístico Morabitur, situado no Aeroporto do Sal, que não se mostrou disponível para colaborar nesta investigação.

\subsection{Recolha quantitativa}

O inquérito por questionário desta investigação foi utilizado com dois propósitos: apurar que fontes de informação consultadas pelos turistas portugueses sobre Cabo Verde e descobrir como avaliam a promoção turística deste destino.

Para melhor dar conta dos momentos "antes" e "depois" da viagem, a amostra de respondentes foi dividida em duas: a dos turistas portugueses que já tinham viajado para Cabo Verde e a dos turistas portugueses que nunca tinham visitado Cabo Verde. Assim sendo, elaborámos dois modelos de questionário, compostos por 11 questões, de forma a averiguar o que os turistas valorizam na promoção de um destino turístico, como avaliam a comunicação e a promoção turística de Cabo Verde no geral, como avaliam a comunicação de intervenientes públicos e privados, tais como o Portal do Turismo de Cabo Verde, agências de viagens, operadores turísticos, brochuras turísticas, entre outros e o que, na sua opinião, necessita de melhorias na promoção do destino Cabo Verde. O propósito do estudo foi explicado a todos os inquiridos, sendo garantidas a confidencialidade e o anonimato dos seus dados.

A amostra dos inquiridos em Cabo Verde foi constituída por um total de 182 turistas portugueses de partida do aeroporto Cesária Évora na ilha de São Vicente, em Cabo Verde, com destino a Lisboa. Os inquéritos foram aplicados de Julho a Setembro de 2014, na sala internacional de embarque do aeroporto da referida ilha, por uma das investigadoras. A amostra utilizada foi de conveniência, já que inquirimos apenas os turistas portugueses que se encontravam na sala internacional de embarque de partida para Lisboa e que estavam disponíveis para responder ao questionário. Depois de tentativas infrutíferas de aplicar inquéritos a turistas portugueses de partida para Cabo Verde no aeroporto de Lisboa, não tendo chegado a obter a necessária autorização, optámos por estudar indivíduos portugueses que que estiveram presentes na "Feira Das Viagens" e nunca tivessem viajado para Cabo Verde. A feira foi realizada em Lisboa na Praça de Touros do Campo Pequeno, durante os dias 8 a 10 de Maio de 2015. Cabo Verde foi um dos destinos a ser promovido, sendo este o motivo pelo qual escolhemos esta feira. Esta amostra foi constituída por um total de 103 portugueses que nunca tinham viajado para Cabo Verde. A caraterização de ambas as amostras consta do Gráfico 5.

De notar que, por constrangimentos temporais e financeiros, se recorreu a amostras não-probabilísticas, em que a escolha dos respondentes não foi aleatória. Desta forma, não existe um controle estatístico de representação do universo em investigação, não pode calcular-se a margem de erro e não está garantida 
a representatividade dos resultados, que não podem ser generalizados para a população (Creswell, 2014). As amostras não-probabilísticas apresentam, ainda assim, vantagens de flexibilidade e podem permitir apurar dados relevantes para estudos exploratórios como este.

\section{Gráfico 5: Caraterização dos inquiridos em Portugal e em Cabo Verde}

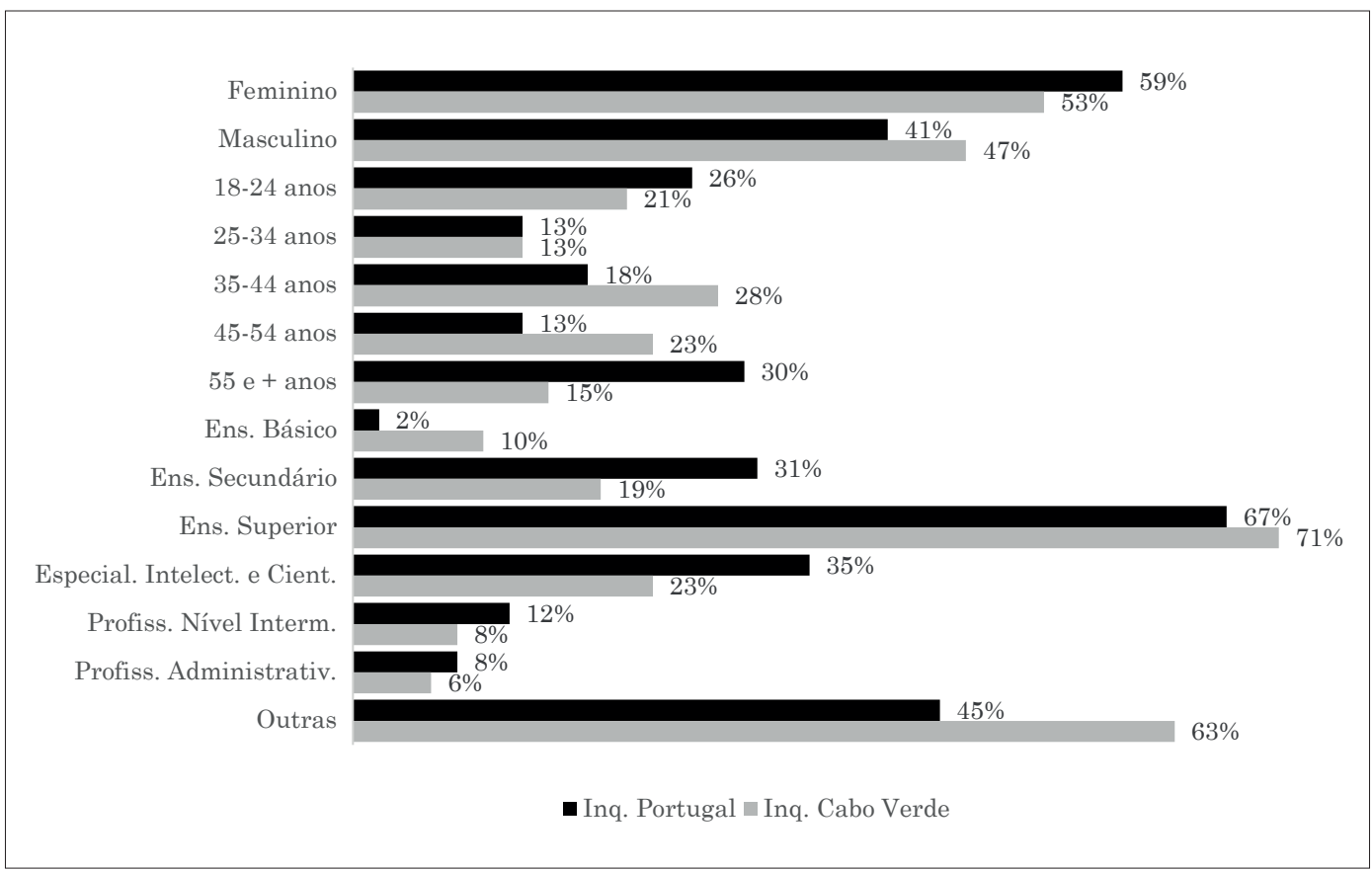

Base: 182 inquiridos em Cabo Verde e 103 inquiridos em Portugal. Elaboração própria.

Os dados resultantes da aplicação do inquérito por questionário das duas amostras foram analisados através do programa IBM SPSS Statistics, versão 23.0.

\section{Resultados}

\subsection{Marketing, promoção de Cabo Verde enquanto destino turístico}

As ilhas de Cabo Verde possuem pouca representatividade numa lógica de promoção autónoma e individual, motivo pelo qual foram segmentadas, tendo em conta o produto central de cada uma. O processo de segmentação baseou-se na organização dos atuais mercados emissores por principal motivação de visita. Deste modo, constituíram-se três grupos diferentes denominados: ilhas do Sol, ilhas da Essência e ilhas dos Sentidos. As ilhas do Sol são constituídas pelas ilhas do Sal, Boavista e Maio, o principal produto turístico é o Sol e o mar (turismo náutico), as ilhas da Essência são constituídas pelas ilhas de São Vicente e Santiago, o principal produto é a cultura e os negócios (turismo cultural, turismo de negócios e turismo náutico) e, finalmente, o grupo das ilhas dos sentidos, constituído pelas ilhas de Santo-Antão, São Nicolau, Fogo e Santa Luzia, sendo o principal produto a natureza (turismo de natureza).

O posicionamento sendo um passo importante no marketing de um destino, carateriza a sua identidade, distinguindo-o dos demais. Cabo Verde, em termos turísticos, posiciona-se como "destino de sol e mar por excelência, de clima tropical, com temperaturas médias anuais de 25 graus, estável em termos políticos, económicos e sociais, seguro, próximo da Europa, com uma oferta turística diversificada" (Plano de Marketing para o Turismo de Cabo Verde 2015/2016). 
Uma das primeiras etapas da atuação promocional de um destino é criar a sua identidade, ou a sua marca, pois esta identidade será aplicada e estará presente em toda a sua existência, em todas as suas atividades. Deste processo, fazem parte os símbolos, a criatividade, o grafismo e os valores de comunicação gerando duas peças muito evidentes que são os logótipos e o slogan ou claim (Madeira, 2010, p. 81).

A marca Cabo Verde é bastante recente. No início de 2010, Cabo Verde ainda não possuía uma marca que revelasse aos seus potenciais clientes (turistas), os seus atributos. Assim sendo, iniciou-se um processo de criação da marca, enquanto destino turístico, tendo sido analisados os atributos do país, através da opinião de stakeholders, turistas e operadores turísticos. O processo de criação da marca Cabo Verde resultou de um Concurso Nacional para a Criação do Logótipo da Marca Turística do país, onde foram validadas 151 propostas, de indivíduos de nacionalidade cabo-verdiana, não sendo possível a participação a pessoas coletivas. O concurso deu origem a um logótipo representativo da marca umbrella do país. Por ser um país constituído por ilhas com caraterísticas próprias, Cabo Verde possui o logótipo do país como um todo e os logótipos dos grupos de ilhas (ilhas do Sol, Essência e dos Sentidos) transmitindo assim mais do que uma mensagem. As mensagens associadas aos logótipos de Cabo Verde como um todo, e das ilhas, foram idealizadas tendo por base a imagem que se pretende criar na mente dos atuais e potenciais clientes do destino: diversidade e experiência - "Um país, dez destinos". Esta mensagem traduz a ideia de que, sendo um único país, consegue-se vivenciar uma enorme variedade de experiências, permitindo atrair um conjunto de segmentos distintos entre eles, de acordo com as suas motivações de viagens, tudo isso graças as particularidades das suas dez ilhas.

Por concorrentes de um destino designam-se outros destinos que estão posicionados de forma análoga. No caso de Cabo Verde, consideram-se concorrentes diretos os destinos que possuem caraterísticas semelhantes, ou produtos turísticos semelhantes (Sol, Mar, Natureza e Cultura). No plano de Marketing para o Turismo de Cabo Verde 2015/2016, consideraram-se os seguintes critérios: produto (Sol e Mar, Natureza e Cultura), distância do mercado, preço, variação do clima, para definir os concorrentes de Cabo Verde. A partir da sua definição, observam-se como principais concorrentes do destino: Espanha e ilhas, Tunísia, Marrocos, Itália, Maldivas, Maurícias, Portugal, Croácia, Brasil (destinos cujos produtos turísticos principais são o Sol e Mar); Açores, Madeira, Moçambique, Quénia, Tanzânia, Maurícias (destinos cujo produto turístico principal é a natureza); Itália, Tunísia, Marrocos e Espanha (destinos cujo produto turístico principal é a Cultura).

A promoção do destino Cabo Verde está oficializada na Lei no 84/VII/2011, que instituiu que a promoção turística de Cabo Verde tem como principal objetivo a comunicação eficaz do país, visando o aumento dos fluxos e consumos turísticos, e a progressiva diversificação de mercados emissores de turistas e investidores no turismo, com o consequente aumento da receita turística. O mesmo documento refere que a comunicação turística deverá ser desenvolvida em torno dos seguintes eixos:

a) Posicionamento da marca do país, baseado em fatores distintivos sólidos que sustentam uma comunicação eficaz e adequada aos segmentos preferenciais da procura;

b) Reforço e desenvolvimento das marcas das várias ilhas em articulação com a marca "Cabo Verde";

c) Progressiva participação do setor privado no esforço de promoção, designadamente nos respetivos processos de decisão e financiamento;

d) Crescente profissionalização das entidades com responsabilidades na promoção externa, assegurando a representatividade dos agentes públicos e privados nessas entidades;

e) Captação de eventos internacionais;

f) Promoção e divulgação da morabeza e da cultura cabo-verdiana como fator distintivo e de afirmação do país.

Os objetivos concernentes à estratégia de Comunicação de Cabo Verde enquanto destino turístico são (Plano de Marketing para o Turismo de Cabo Verde 2015/2016):

a) Dar a conhecer o destino junto dos visitantes potenciais (aumentar a notoriedade de Cabo Verde e estimular a vontade de visita (estratégia pull);

b) Manter a comunicação B2B (business to business) e aumentar a comunicação B2C (business to consumer);

c) Dirigir a promoção aos segmentos de mercado com apetência para viajar para Cabo Verde;

d) Promover todas as ilhas, comunicando-se as especificidades de cada uma.

A Direção Geral do Turismo de Cabo Verde (DGT, entidade oficial) promove o país tanto a nível interno, ou nacional, como a nível externo, ou internacional. A promoção turística realizada pela DGT no próprio destino difere da promoção realizada no exterior. 
No destino, incluem-se ações imediatas de promoção propostas no Plano de Marketing para o Turismo de Cabo Verde 2011/2013:

a) Criação do Portal do Turismo de Cabo Verde (www.visitcaboverde.cv);

b) Criação de postos de informação turística (nos aeroportos internacionais de Cabo Verde e nas principais localidades de cada ilha - uma parceria da DGT/ autarquias/ setor privado);

c) Ações de promoção do turismo interno, como, por exemplo campanhas e reportagens televisivas com o objetivo de ilustrar a oferta de cada grupo de ilhas - Sol e Praia, Cultura e Negócios, além de Património Natural e Paisagem - incentivando assim o turismo doméstico;

d) Outdoors de cada produto;

e) Participação em feiras de interesse a nível nacional ou local tais como a Expotur.

Relativamente à promoção realizada no exterior, as ações imediatas são:

a) Participação em feiras, onde o destino é promovido como um todo, dando especial enfoque ao produto dirigido especificamente ao mercado onde se realiza a feira;

b) Presença online e utilização de Google Adwords, bem como a criação de botões de acesso ao website do turismo de Cabo Verde;

c) Estabelecimento de parcerias com associações internacionais que se dediquem a temas associados aos produtos específicos de Cabo Verde para organização conjunta de eventos;

d) Realização de press-trips para atrair jornalistas dos meios de comunicação internacionais;

e) Associação a eventos do setor privado de carácter nacional e internacional, participando em workshops ou apoiando fam-trips ao destino.

\subsection{Papel das instituições públicas e privadas na promoção turística de Cabo Verde}

Através da análise das entrevistas realizadas, pretendeu-se compreender o papel dos diferentes agentes de promoção turística de Cabo Verde para o mercado exterior, particularmente para o mercado português.

Antes da D.G.T, Cabo Verde era promovido pelo Cabo Verde Investimentos (C.I.); no entanto, esta instituição desempenhava funções e objetivos com caraterísticas diferentes e passiveis de confusão. Para além de promover Cabo Verde enquanto destino turístico, a C.I tinha como função atrair investimentos estrangeiros para o país, pelo que esta componente vinha assumindo uma relevância superior, acabando por ficar em segundo plano a promoção do destino turístico (Plano Estratégico para o Desenvolvimento do Turismo em Cabo Verde 2010/2013, p.79). Mesmo existindo estas lacunas, o país tem vindo a dar os seus primeiros passos relativamente à sua promoção turística, atualmente existe os dois planos de marketing (2011/2013; 2015/2016), sendo que, cada vez mais, tem aumentado as suas participações em Feiras de Turismo Internacionais. Igualmente tem-se adotado estratégias no sentido de melhorar a promoção do destino, como por exemplo a criação da Agência do Turismo e Investimentos de Cabo Verde (ATIC).

A Direção Geral do Turismo de Cabo Verde (DGT) é a instituição oficial responsável pela promoção turística do destino. Para além das inúmeras funções que lhe são atribuídas, compete-lhe: conceber e promover a imagem de Cabo Verde como destino turístico nos mercados interno e externo, em estreita articulação com outros serviços e organismos do setor; e ainda definir e assegurar a aplicação da política de promoção turística do país.

De acordo com informações obtidas no Ministério de Turismo, Investimentos e Desenvolvimento Empresarial (MTIDE), as decisões políticas recentes determinaram a concentração da responsabilidade da promoção de Cabo Verde (enquanto destino turístico) na DGT, e consequentemente, estabeleceu-se um período de phasing-out onde a CI apoia e colabora com a mesma na preparação e participação em feiras internacionais de turismo. Para além das feiras internacionais, a DGT/MTIDE (com apoio da CI) tem feito um esforço na promoção da marca turística Cabo Verde e respetivo slogan através de merchandising, participação em eventos culturais e desportivas, organização de fam-trips, elaboração de vídeos promocionais do país, e também da organização da feira Expotur.

O MTIDE acrescenta ainda que a DGT é efetivamente o órgão público responsável pela promoção turística do país. Entretanto, outras instituições são envolvidas, nomeadamente a Cabo Verde Investimento (focada na atração de investimentos) e a Câmara de Turismo. Existem ainda outros ministérios que acabam por também promover o destino, nomeadamente o Ministério das Relações Externas, da Cultura, do Desporto. As Câmaras Municipais também têm vindo a fazer algum trabalho, embora tímido, no que toca à promoção das localidades turísticas. Porém, existe a convicção de que o turismo e 
a imagem do destino Cabo Verde têm sido muito mais moldados pelas forças do mercado e agenda dos operadores internacionais (demand driven) do que por planeamento pró-ativo e estratégias colaborativas intersetoriais ou público-privados (supply driven).

A promoção é realizada através do website do Portal do Turismo de Cabo Verde (www.turismo. cv), organizado de acordo com a oferta atual que resultou do agrupamento das ilhas e em virtude da calendarização dos eventos ou festividades realizados no destino. Por outro lado, é admitido que o referido website carece de melhorias e atualizações. São utilizadas as redes sociais digitais, como a página no Facebook, mas não se aproveita cabalmente as vantagens que este meio proporciona, sendo que a respectiva página necessita igualmente de melhorias e atualizações.

Note-se ainda que Cabo Verde começa a estar presente na oferta de operadores turísticos que vendem pacotes de sol e praia, ainda que sejam os operadores turísticos portugueses os que têm desenvolvido, em maior medida, a venda do destino (Canalejo et al., 2014, p. 373). A realização das entrevistas aos intervenientes privados portugueses revelou que apenas os operadores turísticos Soltrópico e Solférias participam na promoção do destino. Estes operadores promovem turisticamente Cabo Verde em Portugal (ambos) e noutros mercados (Soltrópico). A agência de viagens Abreu afirmou não participar diretamente na promoção do destino, já que a promoção é efectuada por operadores turísticos, cabendo-lhes a venda dos pacotes ao consumidor final.

A Soltrópico nasceu "sob o signo de Cabo Verde" há 25 anos e continua até hoje a ser líder de mercado neste destino. A promoção de Cabo Verde enquanto destino turístico realizada pela Soltrópico é feita sempre como um todo e também nas operações regulares e charters onde existe maior interesse comercial de divulgação. Na promoção do destino são tidos em conta os seguintes fatores: identidade e proximidade cultural, proximidade geográfica, facilidade de comunicação, sol, praia e cultura e as ligações aéreas. Promove-se o país tanto para o mercado português como para o mercado espanhol, alemão, holandês, belga e luxemburguês. Como ferramentas de comunicação utiliza essencialmente workshops, roadshows e newsletters. Relativamente aos meios de comunicação, privilegia a internet.

A Solférias promove Cabo Verde desde 2010. Em termos gerais, a sua promoção é feita através de várias ações no mercado português: publicação anual de duas brochuras do destino, distribuídas em todas as agências de viagens nacionais; realização anual de um roadshow em quatro cidades portuguesas com informação sobre o país; participação em várias feiras de turismo promovendo Cabo Verde, nalguns períodos pontuais, são programadas campanhas publicitárias de rádio e outdoors do destino, fam trips e press trips para divulgação do destino. A promoção do país é igualmente feita através de banners em vários jornais do turismo online e com algumas publicações no Facebook. Tendo em conta as ações generalistas, o país é promovido como um todo, mas algumas campanhas de rádio e outdoors são específicas para as ilhas de maior afluência turística (Sal e Boavista). A promoção do destino é realizada tendo em conta a proximidade geográfica, sol e praia, natureza, gastronomia, cultura, música, segurança, e saúde, uma vez que para visitar o destino não há obrigatoriedade de vacinas ou medicação específica. São usados publicidade, promoção de vendas e webmarketing. Nos meios de comunicação, destacam-se rádio, imprensa, outdoors e internet. Relativamente às parcerias com outros stakeholders, a Solférias tem parcerias com alguns hoteleiros, nomeadamente em campanhas publicitárias. Quanto a parcerias com as instituições oficiais cabo-verdianas, o operador é sócio da Câmara de Turismo de Cabo Verde, participando anualmente na feira de Turismo de Cabo Verde (Expotur).

Com a realização das entrevistas aos intervenientes privados cabo-verdianos (hotéis e agências de viagens), constatou-se que as promoções dessas instituições são realizadas apenas para o mercado interno, utilizando essencialmente a internet (websites, redes sociais online), feiras de turismo nacionais e os meios de comunicação locais (rádio, imprensa, televisão, revistas). Quanto aos hotéis entrevistados (Dom Paco e Porto Grande), acreditam que não conseguem promover-se sem promover o destino em que o hotel está inserido, realizando as suas promoções apenas a nível nacional. A promoção para o mercado exterior é realizada por operadores turísticos tais como Booking.com, Expedia, Hotel Beds, Tripadvisor e pelo Grupo Oásis Atlântico (Hotel Porto Grande).

Para encerrar este ponto, frise-se que várias respostas obtidas alertaram para a inexperiência de algumas instituições oficiais envolvidas na promoção turística do destino. A promoção oficial das ilhas de Cabo Verde foi acusada de vir sendo feita de forma algo descoordenada, praticamente por cada operador ou entidade de forma individual e com a sua própria estratégia de comunicação.

\subsection{Fontes de informação dos turistas portugueses sobre Cabo Verde}

Um estudo realizado para o Plano de Marketing do Turismo de Cabo Verde 2015/2016 sobre a procura do destino, na qual foi tida em conta uma análise do perfil e grau de satisfação do mercado dos 
visitantes atuais de Cabo Verde, concluiu que os aspetos mais valorizados pelo mercado dos visitantes atuais eram o sol, o mar, a hospitalidade, o clima e a natureza. Os aspetos menos apreciados eram, por outro lado, a informação turística, os monumentos, a oferta comercial e a infraestruturação dos espaços públicos. A maioria dos turistas inquiridos disse ter por hábito reservar a sua viagem através de agências de viagens ou operadores turísticos, optando por pacotes que incluem voo, alojamentos e outros serviços. Mais de $90 \%$ dos turistas afirmaram estar muitos satisfeitos com a visita a Cabo Verde e 88\% declararam recomendar muitas vezes ou sempre Cabo Verde como destino de férias.

Estabeleceu-se como objetivo deste artigo apurar que fontes de informação os turistas portugueses consultaram antes de viajarem. No Gráfico 6 podemos ver as respostas dos inquiridos em Portugal e em Cabo Verde.

\section{Gráfico 6: Fontes de informação dos inquiridos sobre Cabo Verde como destino turístico}

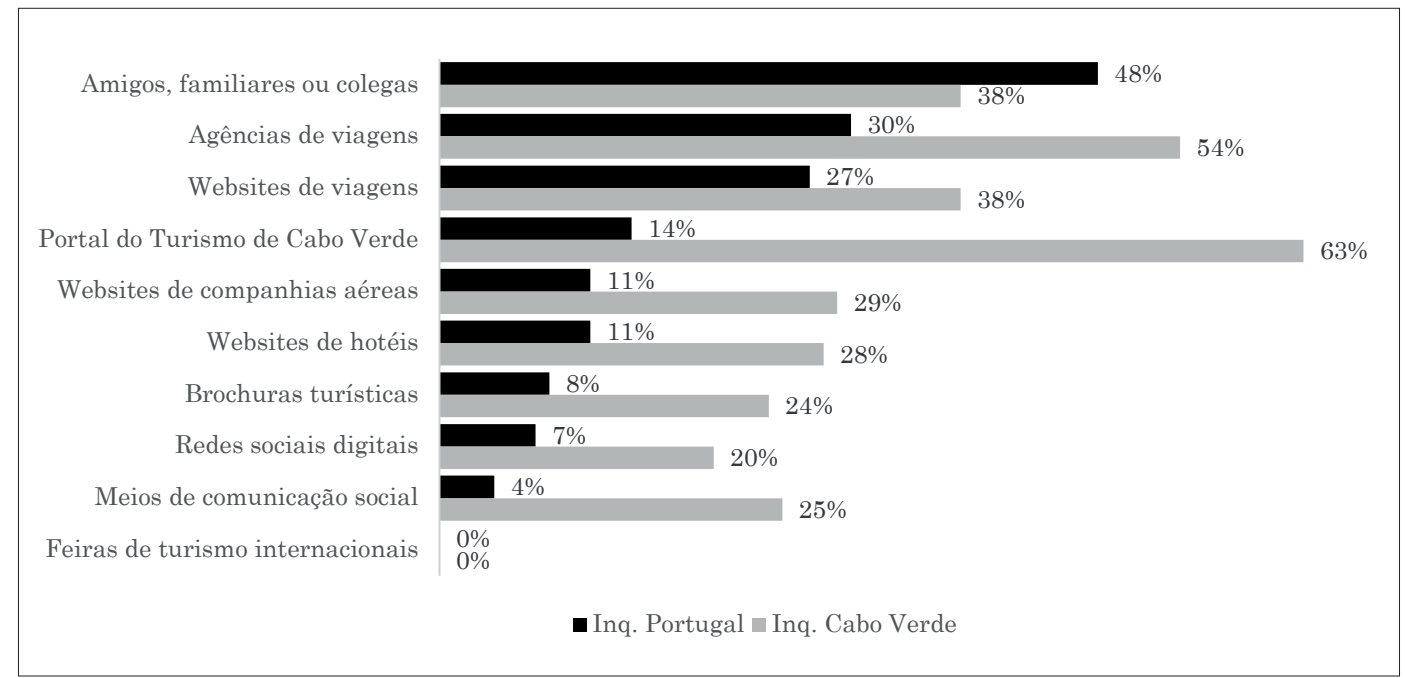

Base: 182 inquiridos em Cabo Verde e 103 inquiridos em Portugal. Elaboração própria.

Dos respondentes em Cabo Verde, $48 \%$ diz ter consultado principalmente amigos, familiares e colegas para se aconselharem sobre o destino. Isto vai ao encontro da perspetiva de quem defende que o WOM na atividade turística é uma das mais importantes formas de divulgação de um destino ou serviço turístico, já que as opiniões destes grupos de referência têm uma forte influência sobre o destino de férias e as atividades escolhidas (Bolaños et al., 2014). As agências de viagens (30\%) e os websites de viagens (27\%) foram a segunda e terceira fontes mais consultadas. Apenas $14 \%$ dos inquiridos referiram o website do Portal do Turismo de Cabo Verde (14\%). Websites de companhias aéreas e websites de hotéis foram mencionados por $11 \%$ dos respondentes; brochuras turísticas por $8 \%$; redes sociais digitais por $7 \%$ e meios de comunicação social por 4\%. Ninguém apontou as feiras de turismo internacionais. Algumas destas fontes exerceram pouca ou nenhuma influência, o que poderá ser justificado pelo fato da D.G.T. apostar pouco nos meios de comunicação social, e nas redes sociais digitais.

Abordando agora as fontes de informação os inquiridos portugueses que nunca visitaram o destino consultariam antes de viajarem para Cabo Verde, sobressai um resultado diferente do primeiro grupo de respondentes: o website do Portal do Turismo de Cabo Verde seria a fonte que $63 \%$ dos inquiridos consultariam, seguido das agências de viagens (54\%). Amigos, familiares e colegas, embora mantendo grande importância, surgem apenas em terceiro lugar (38\%). A maioria destes inquiridos aparenta depositar confiança no website do Portal do Turismo de Cabo Verde, considerado a primeira fonte que consultariam - o que denota as expetativas dos turistas relativamente à fonte de informação oficial do destino e gera, consequentemente, a chamada de atenção para a necessidade de atender a tal solicitação. Com efeito, de todas as formas de divulgar ou promover um destino turístico, o website de turismo 
desse destino é o que deve fornecer as mais variadas e melhores informações, carecendo de constante atualização (Quaresma et al., 2018).

Dos aspetos mais valorizados na promoção do destino por quem visitou Cabo Verde (Gráfico 7), a promoção online foi o item mais escolhido (57\%), seguindo-se-lhe os meios de comunicação social (36\%) e as feiras de turismo internacionais (18\%). Comparando estas preferências com a resposta de quem aconselhou o destino, apesar dos visitantes inquiridos valorizarem mais a promoção online e nos meios de comunicação, foram os amigos, familiares e colegas que mais influenciaram a sua escolha de Cabo Verde. Esta aparente contradição pode ser justificada pelo fato de a promoção do destino Cabo Verde online e nos meios de comunicação social ser ainda fraca, apesar dos estudos que indicam a valorização crescente da divulgação, sobretudo online, pelos turistas (Fernandes et al., 2018; Quaresma et al., 2018). Semelhantemente aos inquiridos visitantes do país, os respondentes em Portugal preferem a promoção online (50\%), nos meios de comunicação social (21\%) e em feiras de turismo internacionais (26\%).

\section{Gráfico 7: Aspetos valorizados pelos inquiridos na promoção turística de Cabo Verde}

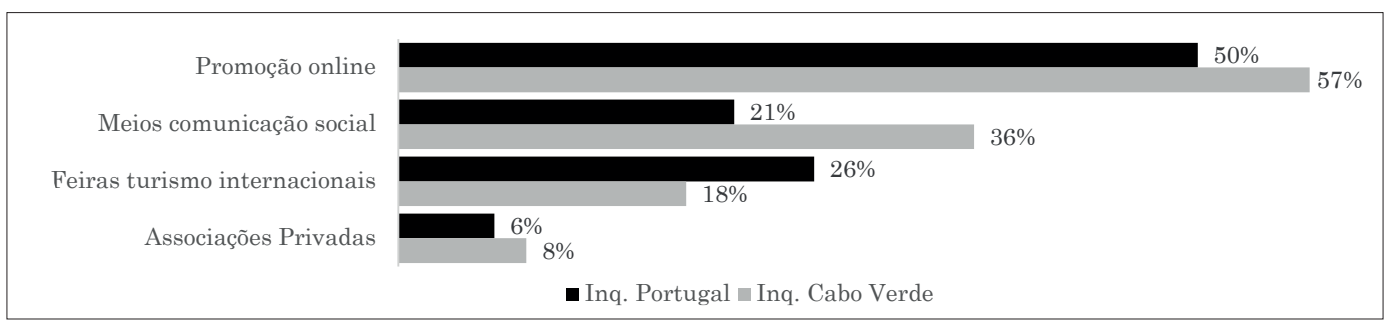

Base: 182 inquiridos em Cabo Verde e 103 inquiridos em Portugal. Elaboração própria.

Sobre como como os turistas portugueses avaliam a promoção turística do destino Cabo Verde, os Gráficos 8 e 9 resumem as suas opiniões.

\section{Gráfico 8: Avaliação dos inquiridos sobre a promoção turística de Cabo Verde}

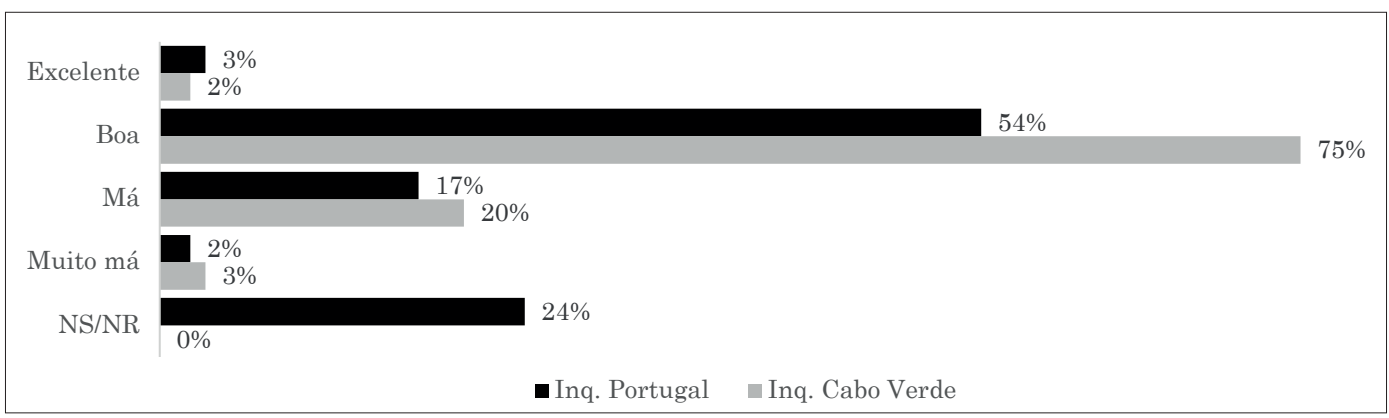

Base: 182 inquiridos em Cabo Verde e 103 inquiridos em Portugal. Elaboração própria.

$78 \%$ dos inquiridos que viajaram para Cabo Verde disseram ter da promoção turística do destino uma perceção positiva (sendo que $4 \%$ lhe atribuíram uma nota excelente). Já $23 \%$ destes inquiridos não apreciaram favoravelmente a promoção do destino cabo-verdiano. Também a avaliação da promoção turística de Cabo Verde por quem não viajou ainda para este destino revela oportunidades de melhoria: $24 \%$ declararam não ter daquela qualquer conhecimento, enquanto $57 \%$ entenderam ser boa, ou excelente e os restantes $20 \%$ má, ou muito má.

Quanto à avaliação que os inquiridos fazem de cada um dos emissores da promoção turística de Cabo Verde, realce para a nota positiva obtida pelas agências de viagens, contrastando com a avaliação negativa de todos os outros aspetos avaliados, como se constata no Gráfico 9. 


\section{Gráfico 9: Aspetos avaliados positivamente na promoção turística de Cabo Verde}

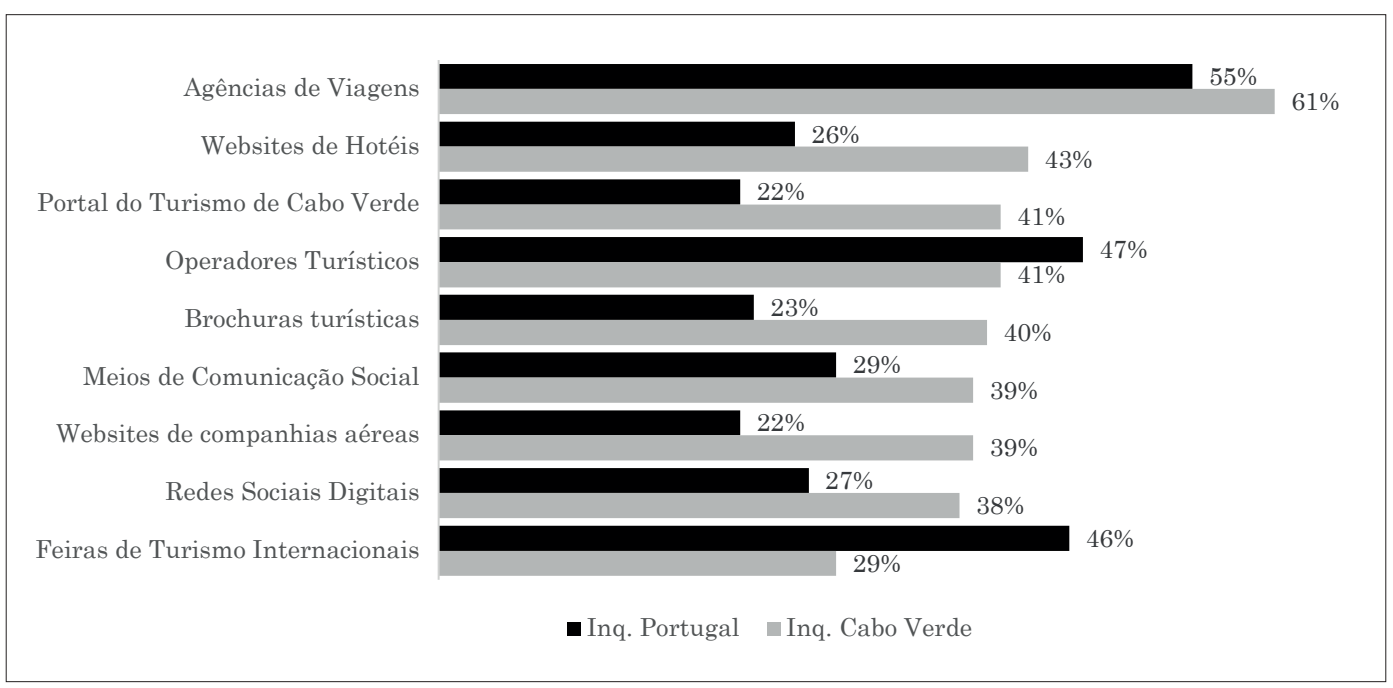

Base: 182 inquiridos em Cabo Verde e 103 inquiridos em Portugal. Elaboração própria.

Relativamente a sugestões de melhorias na promoção do destino Cabo Verde, todos os itens considerados (Portal do Turismo de Cabo Verde, redes sociais digitais, feiras de turismo internacionais, meios de comunicação social, agências de viagens, operadores turísticos, websites de hotéis, websites de companhias aéreas e brochuras turísticas) necessitam de intervenções, no entender dos inquiridos em Cabo Verde, fato que a ter em consideração no desenvolvimento da promoção do turismo de Cabo Verde. $41 \%$ dos inquiridos defenderam, particularmente, mais promoção nos meios de comunicação social e $31 \%$ pediram mais promoção no website do portal do turismo de Cabo Verde.

Cruzando as respostas obtidas com o perfil sociodemográfico dos inquiridos, ressalta que os inquiridos com habilitações literárias ao nível do ensino superior tendem a valorizar mais a promoção online (66\%) do que os inquiridos com menos habilitações (43\% para o nível secundário e $22 \%$ para o nível básico); do mesmo modo, são estes indivíduos mais instruídos que se pronunciam mais a favor de melhorias na comunicação online do Portal do turismo de Cabo Verde (36\%, contra 13\% dos detentores de instrução secundária e $0 \%$ de instrução básica) e nas redes sociais digitais ( $42 \%$ de inquiridos de habilitações superiores, versus 13\% ao nível do secundário e 0\% do básico). Esta informação pode ser relevante na altura de segmentar os consumidores e públicos pretendidos para o turismo e comunicação turística de Cabo Verde (Ramos \& Ribeiro, 2014).

\section{Conclusões}

A procura pelo destino turístico Cabo Verde tem aumentado gradualmente nos últimos anos. Neste artigo, descreveu-se o processo de promoção turística de Cabo Verde para o mercado exterior, identificando o papel de cada interveniente turístico público e privado. O mercado português, que constituiu o nosso objeto de estudo, é um dos seus principais emissores. Avaliou-se a opinião dos turistas portugueses relativamente à comunicação turística de Cabo Verde e recolheu-se as suas recomendações de melhoria.

Dos resultados obtidos, apurou-se cinco conclusões principais: primeira, a promoção turística de Cabo Verde é recente e, apesar dos esforços da entidade oficial (DGT) por ela responsável, ainda lhe são apontadas lacunas por ser errática, pouco coordenada e insuficiente para atingir os seus públicos pretendidos. Segunda, mormente a crescente evidência científica de que a comunicação online e a cooperação entre stakeholders públicos e privados contribuem decisivamente para o sucesso dos destinos turísticos, estes ainda não são trunfos utilizados no marketing e comunicação turísticos oficiais de Cabo Verde. Terceira, os turistas visados pela comunicação turística de Cabo Verde reconhecem a escassez de divulgação, sobretudo oficial, e solicitam o reforço e a melhoria da comunicação turística deste destino. 
Com efeito, os resultados apontam para a possibilidade de a procura por Cabo Verde poder estar muito dependente de WOM e promoção realizada pelos intervenientes privados, sendo ainda pouco percetíveis resultados das ações realizadas pelas organizações oficiais responsáveis pela promoção do destino. Quarta, os intervenientes privados parecem estar a ser mais dinâmicos na promoção de Cabo Verde do que os responsáveis públicos, o que pode merecer esforços de cooperação para colher melhores resultados para todas as partes interessadas. Quinta, se o WOM tem um papel tão importante na divulgação deste e doutros destinos turísticos, valerá a pena envidar esforços para cultivá-lo e expandi-lo.

A comunicação das organizações responsáveis pela promoção de um destino turístico é uma das mais importantes formas de torná-lo notório e preferido. No caso da DGT de Cabo Verde, parece haver uma grande diferença entre o que se encontra definido no primeiro Plano de Marketing e aquilo que efetivamente está a ser realizado. Apesar de algumas das ações propostas serem de longo prazo, existem ações de curto prazo que não foram implementadas da melhor forma, como a do website do Turismo de Cabo Verde, que necessita de atualizações e melhorias ao nível da riqueza e variedade dos seus conteúdos. Constatou-se também que não são utilizadas com frequência as ferramentas de comunicação e as formas específicas de divulgar um destino, excetuando-se a participação em feiras de turismo, eventos e fam trips.

A principal recomendação para a instituição oficial responsável pela promoção do destino (D.G.T) seria a solidificação da sua aposta no webmarketing (através de websites e redes socais digitais), para promover o destino Cabo Verde, tal como desejam os turistas consultados neste e noutros estudos. As instituições responsáveis pela promoção do destino deveriam melhorar o website do Portal do Turismo de Cabo Verde e a respetiva página do Facebook, indo ao encontro das suas necessidades: estas páginas poderiam divulgar mais informações sobre o destino, publicar fotos e vídeos dos eventos realizados no país, de forma a transmitir um pouco da cultura cabo-verdiana e cativar mais turistas com esses atrativos. Não é despiciendo o facto de este estudo revelar a associação entre habilitações mais elevadas dos turistas e a sua preferência pela comunicação turística online; com isto em mente, Cabo Verde poderá contribuir para qualificar melhor o perfil dos seus visitantes e assim aumentar os seus lucros e possibilidades de desenvolvimento.

Este estudo apresenta limitações, salientando-se a incipiência da literatura sobre o destino em análise e a amostragem não representativa dos inquiridos. Em estudos futuros, recomenda-se o recurso a amostras representativas e alargadas a outras nacionalidades de mercados emissores. Seria interessante realizar-se um estudo comparativo entre Cabo Verde e os seus concorrentes, para apurar razões de sucesso e prevenir causas de insucesso. Um melhor conhecimento das necessidades e expetativas dos turistas poderia ser obtido com recurso a técnicas qualitativas. Não obstante as suas fraquezas, considera-se que esta pesquisa contribui para o conhecimento e a melhoria da comunicação turística de Cabo Verde, cujo exemplo pode servir a outros países em desenvolvimento e aos seus estudiosos.

A partir da análise efectivada considera-se que as implicações específicas para a promoção do turismo em Cabo Verde poderão ser as seguintes: sabendo que a comunicação turística do destino está dependente de operadores turísticos ou de intervenientes privados é necessário implementar um conjunto de melhorias face às estratégias de comunicação turística, nomeadamente a comunicação online, deste modo poder-se-ia atingir os públicos pretendidos. Apesar de a promoção turística de Cabo Verde ser recente e, serem notórios esforços por parte da entidade oficial (DGT) por ela responsável, o facto de ser errática, pouco coordenada e insuficiente para atingir os públicos pretendidos tem consequências não apenas na avaliação dos inquiridos face à comunicação como também na forma como a mensagem chega ao consumidor final.

\section{Bibliografia}

Balanzá, I. M. \& Nadal, M. C.

2003. Marketing e Comercialização de Produtos Turísticos. São Paulo: Thomson.

Baptista, M.

2003. Turismo: Gestão Estratégica. Lisboa: Verbo.

Bolaños, I., Ribeiro, R., \& Ramos, B. A.

2014. O poder do word-of-mouth e do conteúdo gerado por utilizadores na comunicação turística: o caso de uma agência de viagens à medida. Revista Turismo \& Desenvolvimento, 2(21), 13-22. 
Buhalis, D.

2000. Tourism and Information Technologies: Past, Present and Future. Tourism Recreation Research, 25 (1), 41-58.

Canalejo, A., C., Guzmán, T., Lopez, J., Ribeiro, M.

2014. O Turismo em Cabo Verde: Situação atual e tendências. Costa, C., Brandão, F., Costa, R., Breda, Z., (Eds.). Turismo nos Países Lusófonos: Conhecimento, Estratégia e Territórios (pp. 367-382). Lisboa, Escolar Editora.

Carmo, H., \& Ferreira, M. M.

2008. Metodologia da Investigação - Guia para Auto-Aprendizagem. Lisboa: Universidade Aberta.

Cosma, S., Bota, M. \& Tutunea, M.

2012. Study about customer preferences in using online tourism Products. Procedia Economics and Finance, 3, 883-888.

Costa, J., Rita, P. \& Águas, P.

2001. Tendências Internacionais em Turismo. Lisboa: Lidel.

Creswell, J. W.

2014. A concise introduction to mixed methods research. London: Sage Publications.

Cunha, L.

2013. Economia e Política do Turismo. Lisboa: Lidel.

Esu, B. B.

2010. Promoting an Emerging Tourism Destination. Global Journal of Management and Business Research, 10, 21-28.

DiPietro, R., Wang, Y., Rompf, P., \& Severt, D.

2007. At-destination Visitor Information Search and Venue Decision Strategies. International Journal of Tourism Research, 9(3), 175-188.

Fernandes, F., Ribeiro, R. \& Ferreira, A.

2018. A Comunicação de Portugal como destino de Surf: análise exploratória. Revista Turismo \& Desenvolvimento, 1(27/28), 703-712.

Fernandes, F.

2016. Abordar o marketing turístico. Ribeiro, R. B. (coord.), Marketing: do conhecimento à decisão (pp.319-327). Lisboa: Causa das Regras.

Fernandes, F.

2016. Turismo, espaços, potencialidades e produtos: uma viagem pela CPLP. Sebastião, S. P. (coord.), Comunidade dos países de língua portuguesa. A afirmação global das culturas de expressão portuguesa (pp.137-160). Lisboa: Instituto Superior de Ciências Sociais e Políticas, Universidade de Lisboa.

Font, X., \& McCabe, S.

2017. Sustainability and marketing in tourism: its contexts, paradoxes, approaches, challenges and potential. Journal of Sustainable Tourism, 25(7), 869-883.

INE CV - Instituto Nacional de Estatística de Cabo Verde

2014. Estatísticas do Turismo 2013. Retrieved from http://ine.cv/wp-content/uploads/2016/11/estatisticas-do-turismo-2013.pdf.

INE CV - Instituto Nacional de Estatística de Cabo Verde

2015. Estatísticas do Turismo 2014. Retrieved from http://ine.cv/wp-content/uploads/2016/11/estatisticas-do-turismo-2014.pdf.

Kotler, P., Kartajaya, H., \& Setiawan, I.

2010. Marketing 3.0: From products to customers to the human spirit. John Wiley \& Sons.

Lei $n^{0}$ 84/VII/2011. Retrieved from http://www.sdtibm.cv/documentos/BO/bo_I_10-01-2011_2.pdf.

Madeira, N.

2010. Marketing e Comercialização de Produtos e Destinos. Porto: Princípia Editora, Lda.

Marujo, M. N.

2008. Turismo e Comunicação. Castelo Branco: RVJ-Editores.

Ministério de Turismo, Investimentos e Desenvolvimento Empresarial

2015. Plano de Marketing do Turismo de Cabo Verde 2015-2016. Praia.

OMT - Organización Mundial del Turismo

1998. Introducción al Turismo. Madrid: Organización Mundial del Turismo.

Quaresma, C., Ribeiro, R., \& Fernandes, F.

2018. A utilização da web na promoção do Enoturismo na região Oeste de Portugal. Revista Turismo \& Desenvolvimento, 1(27/28), 1489-1499. 
Ramos, B. A. C. R., \& Ribeiro, R. B.

2014. Aldeias do Xisto: a estratégia de marketing e comunicação de uma marca territorial. Revista

Turismo \& Desenvolvimento, 3(21), 13-23.

Ribeiro, R. B.

2016. Os mercados da CPLP: caraterização e perspetivas. Sebastião, S. P. (coord.), Comunidade dos países de língua portuguesa. A afirmação global das culturas de expressão portuguesa (pp.101-135).

Lisboa: Instituto Superior de Ciências Sociais e Políticas, Universidade de Lisboa.

Ribeiro, R. B., \& Soares, I.

2015. Marketing / Marketing Science. Cook, Daniel e Ryan, J. Michael (eds.). The Wiley-Blackwell

Encyclopedia of Consumption and Consumer Studies (pp. 389-393). John Wiley \& Sons Ltd.

Rita, P. \& Antunes, J.

2014. A Importância do Marketing no Desenvolvimento de Destinos e Produtos Turísticos. In Carlos Costa, Filipa Brandão, Rui Costa \& Zélia Breda (Eds), Turismo nos Países Lusófonos: Conhecimento, Estratégia e Territórios. Lisboa, Portugal: Escolar Editora.

Ruschmann, D.

2001. Marketing Turístico. Um Enfoque Promocional. Campinas, São Paulo: Papirus.

Sebastião, S. P.

2016. Comunicação Integrada de Marketing. Ribeiro, R. B. (coord.), Marketing: do conhecimento à decisão (pp. 201-221). Lisboa: Causa das Regras.

UNWTO - Word Tourism Organization

2013. UNWTO annual report 2013. Retrieved from http://cf.cdn.unwto.org/sites/all/files/pdf/unwto_annual_report_2013_0.pdf. 